\title{
Antitumor Effect and Immune Regulation of The Pingyan Capsule on Lewis Lung Cancer Cells in Vivo
}

\author{
$\mathrm{Na} \mathrm{LI}{ }^{1,2}$, Yan LI ${ }^{1, a,{ }^{*}}$ and Tian-yu LIU ${ }^{1}$ \\ ${ }^{1}$ School of Life Science, Beijing Institute of Technology, Beijing 100081,China \\ ${ }^{2}$ Computer Management Center, The General Hospital of Chinese People's Armed \\ Police Forces, Beijing 100039, China \\ *School of Life Science, Beijing Institute of Technology, Beijing 100081,China. \\ aleeyan@bit.edu.cn \\ ${ }^{*}$ Corresponding author
}

Keywords: Lewis lung cancer, Pingyan capsule, antitumor, mononuclear macrophages, immune regulation.

\begin{abstract}
Objective: we investigated the function of Pingyan capsule on antitumor and immune regulation in Lewis lung cancer tumor-bearing mice. Methods: mice were randomly divided into normal control group, model group, positive control group, high, medium and low dose Pingyan capsule groups. Lewis lung carcinoma transplanted tumor model in mice were established. Tumor, thymus and spleen were taken, and the tumor inhibition rate, thymus index, spleen index and carbon clearance were detected. Results: Compared with model group, Pingyan capsule could lose tumor weight in tumor-bearing mice significantly $(\mathrm{P}<0.05)$ and inhibit the growth of tumor. The average inhibitory rate of high, medium and low dose groups were respectively $24.99 \%, 32.72 \%$ and $44.82 \%$. Pingyan capsule could significantly increase the thymus index $(\mathrm{P}<0.05)$, spleen index $(\mathrm{P}<0.05)$ and enhance the function of mononuclear macrophages in Lewis lung cancer bearing-tumor mice $(\mathrm{P}<0.05)$. Conclusions: Pingyan capsule could inhibit the growth of tumor significantly and enhance the immune regulation in Lewis lung cancer bearing-tumor mice. The antitumor mechanism maybe related to the improvement of body's immune function.
\end{abstract}

\section{Introduction}

Lung cancer is one of common malignant tumors in the world at present, which is seriously harmful to human health. The growth rate of lung cancer has reached $111.85 \%$ in recent years ${ }^{[1]}$. Some researches indicate that cancer often declines the immune function of body ${ }^{[2]}$. Chemotherapy is one of the effective method to treat cancer, but cancer patients often have some severe immunosuppression during chemotherapy ${ }^{[3,4,5]}$. The immune system plays a role of immune surveillance in anti-tumor process, so the immune system is pivotal for the treatment of malignant tumors $^{[2]}$. Therefore, it is of great significance to find a drug which could not only inhibit the lung cancer, but also can improve the immune function.

Pingyan capsule is a compound Chinese medicine which is composed of Astragalus, American ginseng, Fritillaria, Dandelion, Forsythia, Curcuma, Snakegourd Fruit, Polygonum bistorta, Snakegourd root and so on. Currently, Pingyan capsule is mainly used in the adjuvant clinical therapy of lung cancer. But it has not been reported about the antitumor mechanisms and immune regulation of the Pingyan capsule. In this study, we established the Lewis lung cancer models in mice and infused the drug to stomach of mice to discuss the antitumor mechanisms and immune regulation of the Pingyan capsule. 


\section{Materials and Methods}

\section{Animals, Cells, Test Drugs and Chemical Reagents}

120 male KM mice, which were purchased from Peking University Health Science Center (Beijing, China), were used. Lewis Lung Cancer cells of mouse were purchased from Tumor Compartment of Chinese Academy of Medical Sciences (Beijing, China). Pingyan capsule which was composed of Astragalus, American ginseng, Fritillaria, Dandelion, Forsythia, Curcuma, Snakegourd Fruit, Polygonum bistorta, Snakegourd root and so on was purchased from Pharmacology and Toxicology department of Beijing Institute of Clinical Drug (Beijing, China). Cyclophosphamide was purchased from Jiangsu Hengrui Medicine Co., Ltd.

\section{Experimental Procedure}

\section{Animals Grouping and Establishment of Lewis Lung Cancer Model in Mice}

Tumor cell samples consist of a ratio of 1:4 the tumor weight to saline. Grinded the samples to cell suspension $\left(1 \times 10^{7}\right.$ cells $\left.\cdot \mathrm{ml}^{-1}\right)$ and inoculated subcutaneously with $0.2 \mathrm{~mL}$ the above cell suspension into the right armpit of mouse except the normal control group. 60 mice were divided into six groups as follows: group 1, 10 mice without tumor cells for NS as normal control group; group 2, 10 mice with tumor cells for NS as model group; group 3, 10 mice with tumor cells for cyclophosphamide $\left(50 \mathrm{mg} \cdot \mathrm{kg}^{-1}\right)$ alone as positive drug group; group 4, 10 mice with tumor cells for high-dose Pingyan capsule $\left(2.48 \mathrm{~g} \cdot \mathrm{kg}^{-1}\right)$ alone; group 5, 10 mice with tumor cells for middle-dose Pingyan capsule $\left(1.24 \mathrm{~g} \cdot \mathrm{kg}^{-1}\right)$ alone; group 6,10 mice with tumor cells for low-dose Pingyan capsule $\left(0.62 \mathrm{~g} \cdot \mathrm{kg}^{-1}\right)$ alone.

\section{Anti-Tumor Experiments on Tumor-Bearing Mice}

After the 60 mice grouped, the drug should be given according to the above method. The normal control group and the model group were given the equal volume of saline by gavage in mice for 15 days continuously. The positive drug group was given cyclophosphamide $\left(50 \mathrm{mg} \cdot \mathrm{kg}^{-1}\right)$ by intraperitoneal injection for $1 \mathrm{~d}, 3 \mathrm{~d}, 5 \mathrm{~d}, 7 \mathrm{~d}, 9 \mathrm{~d}, 11 \mathrm{~d}$, $13 \mathrm{~d}, 15 \mathrm{~d}$. The groups of Pingyan capsule $\left(2.48 \mathrm{~g} \cdot \mathrm{kg}^{-1}, 1.24 \mathrm{~g} \cdot \mathrm{kg}^{-1}, 0.62 \mathrm{~g} \cdot \mathrm{kg}^{-1}\right)$ were given by gavage in mice for 15 days continuously. All the mice were weighed and killed after 15 days. Tumor, thoracic gland and spleen tissues were cut to calculate anti-tumor rate, thoracic gland index and spleen index.

Thymus (spleen) index $=$ thymus (spleen) weight $(\mathrm{g}) /$ body weight $(100 \mathrm{~g})$.

\section{Effect of Monocyte-Macrophage Phagocytosis on Tumor-Bearing Mice}

After the other 60 mice grouped, the drug should be given according to the above method. The normal control group and the model group were given the equal volume of saline by gavage in mice for 7 days continuously. The positive drug group was given cyclophosphamide $\left(50 \mathrm{mg} \cdot \mathrm{kg}^{-1}\right)$ by intraperitoneal injection for $1 \mathrm{~d}, 3 \mathrm{~d}, 5 \mathrm{~d}, 7 \mathrm{~d}$. The groups of Pingyan capsule $\left(2.48 \mathrm{~g} \cdot \mathrm{kg}^{-1}, 1.24 \mathrm{~g} \cdot \mathrm{kg}^{-1}, 0.62 \mathrm{~g} \cdot \mathrm{kg}^{-1}\right)$ were given by gavage in mice for 7 days continuously. Given diluted 2-fold India ink juice $(0.1$ $\left.\mathrm{mL} \cdot 10 \mathrm{~g}^{-1}\right)$ by tail vein injection in an hour after the last administration. Collected $20 \mu \mathrm{L}$ blood from the mice eye socket vEin in mice in $3 \mathrm{~min}$ and $13 \mathrm{~min}$ respectively, then were added the blood to $2 \mathrm{~mL} 0.1 \% \mathrm{Na}_{2} \mathrm{CO}_{3}$ and shaken. Measured absorbance values (A) of each sample in the $680 \mathrm{~nm}$ wavelength with a $0.1 \% \mathrm{Na}_{2} \mathrm{CO}_{3}$ solution as control. The mice were sacrificed after collected blood. Liver and spleen tissues were 
cut to calculate clearance index and phagocytic index.

Clearance index $(\mathrm{K})=\left(\lg \mathrm{A}_{1}-\lg \mathrm{A}_{2}\right) /\left(\mathrm{t}_{2}-\mathrm{t}_{1}\right)$.

Phagocytic index $(\alpha)=\mathrm{K}^{1 / 3} \times$ body weight $/($ liver weight+spleen weight $)$

\section{Statistical Analysis}

Statistical evaluation was done using the SPSS17.0 and ANOVA. Results presented as mean \pm standard deviation $\left(\overline{\mathrm{x}}_{ \pm} \mathrm{SD}\right)$.

\section{Results}

\section{The Inhibition of Pingyan Capsule on Lewis Lung Tumor-Bearing Mice}

Table 1 shows that the average tumor weight of model group is more than $1 \mathrm{~g}$. It indicated the tumor model is successful. Compared with the model group, positive control group was no significant difference in body weight before administration. Although no significant difference in body weight, the cyclophosphamide got the weight down after administration. Compared with the model group, all the Pingyan capsule groups were no significant difference in body weight before or after administration. But the tumor weights of the three groups were significant reduced from the model group $(P<0.05)$. The inhibition rate of animals given high-dose, middle-dose and low-dose Pingyan capsule is $24.99 \%, 32.72 \%$ and $44.82 \%$ respectively.

Table 1. Effect of Pingyan capsule on the tumor proliferation in mice $\left(\overline{\mathrm{X}}_{ \pm \mathrm{SD}}, \mathrm{n}=10\right)$

\begin{tabular}{|c|c|c|c|c|c|}
\hline Group & $\begin{array}{c}\text { Dose } \\
{\left[\mathrm{g} \cdot \mathrm{kg}^{-1}\right]}\end{array}$ & $\begin{array}{c}\text { Body weight } \\
\text { before } \\
\text { administration } \\
{[\mathrm{g}]}\end{array}$ & $\begin{array}{c}\text { Body weight } \\
\text { after } \\
\text { administration } \\
{[\mathrm{g}]}\end{array}$ & $\begin{array}{c}\text { Tumor } \\
\text { weight [g] }\end{array}$ & $\begin{array}{c}\text { anti-tumor } \\
\text { rate [\%] }\end{array}$ \\
\hline $\begin{array}{c}\text { Normal } \\
\text { control }\end{array}$ & - & $21.03 \pm 0.86$ & $35.77 \pm 1.68$ & - & - \\
\hline Model & - & $19.55 \pm 1.10$ & $35.53 \pm 3.15$ & $4.78 \pm 0.92$ & - \\
\hline $\begin{array}{c}\text { Positive } \\
\text { control }\end{array}$ & 0.05 & $19.18 \pm 1.13$ & $27.47 \pm 4.93$ & $0.77 \pm 0.18^{\mathrm{b}}$ & 83.79 \\
\hline $\begin{array}{c}\text { High-dose } \\
\text { Pingyan } \\
\text { Capsule }\end{array}$ & 2.48 & $19.26 \pm 0.76$ & $33.35 \pm 2.77$ & $3.58 \pm 1.11^{\mathrm{a}}$ & 24.99 \\
\hline $\begin{array}{c}\text { Middle-dose } \\
\text { Pingyan } \\
\text { Capsule }\end{array}$ & 1.24 & $19.20 \pm 0.65$ & $33.42 \pm 2.92$ & $3.22 \pm 1.00^{\mathrm{b}}$ & 32.72 \\
\hline $\begin{array}{c}\text { Low-dose } \\
\text { Pingyan } \\
\text { Capsule }\end{array}$ & 0.62 & $19.01 \pm 0.97$ & $30.97 \pm 4.64$ & $2.63 \pm 1.15^{\mathrm{b}}$ & 44.82 \\
\hline
\end{tabular}

${ }^{\mathrm{a}, \mathrm{b}}$ Significantly different from the model group $\left({ }^{\mathrm{a}} P<0.05\right.$, $\left.{ }^{\mathrm{b}} P<0.01\right)$ 
The Effect of Pingyan Capsule on Immune Organ Index of Lewis lung Tumor-Bearing Mice

Table 2. Effect of Pingyan capsule on immune organ index in mice $\left(\bar{x}_{ \pm} S D, n=10\right)$

\begin{tabular}{|c|c|c|c|}
\hline Group & $\begin{array}{c}\text { Dose } \\
{\left[\mathrm{g} \cdot \mathrm{kg}^{-1}\right]}\end{array}$ & $\begin{array}{c}\text { Spleen index } \\
{\left[\mathrm{mg} \mathrm{g}^{-1}\right]}\end{array}$ & $\begin{array}{c}\text { Thymus index } \\
{\left[\mathrm{mg} \mathrm{g}^{-1}\right]}\end{array}$ \\
\hline Normal control & - & $13.68 \pm 0.61$ & $2.19 \pm 0.49$ \\
\hline Model & - & $13.24 \pm 2.89$ & $1.40 \pm 0.55$ \\
\hline Positive control & 0.05 & $14.02 \pm 2.90$ & $0.88 \pm 0.27^{\mathrm{a}}$ \\
\hline $\begin{array}{l}\text { High-dose Pingyan } \\
\text { Capsule }\end{array}$ & 2.48 & $18.76 \pm 2.59^{b}$ & $1.85 \pm 0.30^{\mathrm{a}}$ \\
\hline $\begin{array}{c}\text { Middle-dose Pingyan } \\
\text { Capsule }\end{array}$ & 1.24 & $16.51 \pm 1.24^{\mathrm{a}}$ & $1.80 \pm 0.60$ \\
\hline $\begin{array}{c}\text { Low-dose Pingyan } \\
\text { Capsule }\end{array}$ & 0.62 & $18.18 \pm 3.87^{\mathrm{a}}$ & $1.86 \pm 0.30^{\mathrm{b}}$ \\
\hline
\end{tabular}

${ }^{\mathrm{a}, \mathrm{b}}$ Significantly different from the model group $\left({ }^{\mathrm{a}} P<0.05,{ }^{\mathrm{b}} P<0.01\right)$

Table 2 shows that compared with model group, the thymus index of positive control group was decreased significantly $(P<0.05)$. Thymus index and spleen index of high-dose and low-dose Pingyan capsule groups were increased significantly (both $P<0.05)$. Spleen index of middle-dose Pingyan capsule group was increased significantly $(P<0.05)$. Thymus index of middle-dose Pingyan capsule group was no significantly different from the model group, but there was still a slight increase trend.

The effect of Pingyan Capsule on Mononuclear-Macrophage Phagocytic Function of Lewis Lung Tumor-Bearing Mice

Table 3 shows that compared with model group, the clearance index and phagocytic index of positive control group were no significant difference, but decreased slightly. Compared with the model group, all the clearance index and phagocytic index of Pingyan capsule groups were increased significantly (both $P<0.05$ ). Compared with the positive control group, all the clearance index and phagocytic index of Pingyan capsule groups were also increased significantly (both $P<0.01$ ). 
Table 3. Effect of Pingyan capsule on mononuclear-macrophage phagocytic function in mice $\left(\overline{\mathrm{x}}_{ \pm} \mathrm{SD}\right.$, $\mathrm{n}=10)$

\begin{tabular}{|c|c|c|c|}
\hline Group & $\begin{array}{c}\text { Dose } \\
{\left[\mathrm{g} \cdot \mathrm{kg}^{-1}\right]}\end{array}$ & $\begin{array}{c}\text { Clearance index } \\
\mathrm{K}\left[\times 10^{-3}\right]\end{array}$ & $\alpha$ \\
\hline Normal control & - & $21.44 \pm 7.96$ & $6.73 \pm 1.03$ \\
\hline Model & - & $14.13 \pm 3.34$ & $4.28 \pm 0.51$ \\
\hline Positive control & 0.05 & $11.57 \pm 3.54$ & $3.84 \pm 0.31$ \\
\hline $\begin{array}{c}\text { High-dose Pingyan } \\
\text { Capsule }\end{array}$ & 2.48 & $16.43 \pm 2.92^{\mathrm{c}}$ & $5.07 \pm 0.42^{\mathrm{b}, \mathrm{c}}$ \\
\hline $\begin{array}{c}\text { Middle-dose } \\
\text { Pingyan Capsule }\end{array}$ & 1.24 & $18.21 \pm 1.83^{\mathrm{b}, \mathrm{c}}$ & $4.80 \pm 0.36^{\mathrm{a}, \mathrm{c}}$ \\
\hline $\begin{array}{c}\text { Low-dose Pingyan } \\
\text { Capsule }\end{array}$ & 0.62 & $20.15 \pm 1.96^{\mathrm{b}, \mathrm{c}}$ & $5.45 \pm 0.78^{\mathrm{b}, \mathrm{c}}$ \\
\hline
\end{tabular}

${ }^{\mathrm{a}, \mathrm{b}}$ Significantly different from the model group $\left({ }^{\mathrm{a}} P<0.05,{ }^{\mathrm{b}} P<0.01\right)$

${ }^{\mathrm{c}}$ Significantly different from the positive control group $\left({ }^{\mathrm{c}} P<0.01\right)$

\section{Discussion}

In this study, we found that Pingyan capsule was significantly inhibited tumor growth, the low and middle dose of Pingyan capsule have obvious therapeutic effect on tumor particularly. Cyclophosphamide could inhibit tumor cells but the body weight loss which means the body has been certain damaged. Pingyan capsule may maintain the body's normal growth and development because of the body weight is stable after treated.

It has been found that clinical cancer patients are often accompanied by immune dysfunction and thymic atrophy ${ }^{[6]}$. But Pingyan capsule could enhance thymus, spleen and other organs of the immune function to protect and restore the damaged immune system. The clearance index and phagocytic index were increased after treating with Pingyan capsule. It confirmed the Pingyan capsule could improve immune function to achieve antitumor effect.

In conclusion, as a compound Chinese medicine, Pingyan capsule could inhibit tumor proliferation by enhancing the immune function of body. At the same time as capsules, they are easy to carry than traditional Chinese herbal medicine. It will have broad application prospects and value in the clinical application of adjuvant therapy. But it is still not clear about the molecular mechanism of enhancing the body immunity. We should do further experiments to verify the mechanism. 


\section{References}

[1] D. S. Wan. Clinical Oncology, Science press, Beijing, 2003.

[2] Liu J, Zhang L, Ren Y, Anticancer and immune regulatory activity of Gynostemma pentaphyllum polysaccharides in $\mathrm{H} 22$ tumor-bearing mice, J. International Journal of Biological Macromolecules. 69 (2014) 1-4.

[3] Pal S, Bhattacharyya S, Choudhuri T, Amelioration of immune cell number depletion and potentiation of depressed detoxification system of tumor-bearing mice by curcumin, J. Cancer Detection \& Prevention, 29 (2005) 470-478.

[4] Ting Zhao, Guanghua Mao, Enhanced antitumor and reduced toxicity effect of Schisanreae polysaccharide in 5-Fu treated Heps-bearing mice, J. International Journal of Biological Macromolecules, 63 (2014) 114-118.

[5] Cao Z, Zhang Z, Huang Z, Antitumor and immunomodulatory effects of low-dose 5-FU on hepatoma 22 tumor-bearing mice, J. Oncology Letters, 7 (2014) 1260-1264.

[6] L. F. Yang, R. B. Huang, Y. Jiao. Effect and mechanism of traditional Chinese medicine Kacimex capsules on tumors in vivo J. Lishizhen Medicine and Materia Medica Research. 24 (2013) 869-871. 